\title{
THE IMPLEMENTATION OF GOOD GOVERNANCE IN SUSTAINING WAQF FUND: AN EXPERIENCE OF INDONESIAN WAQF BOARD (BWI)
}

\author{
Marina Abu Bakar ${ }^{1}$, Shofian Ahmad ${ }^{2}$, Ahmad Dahlan Salleh ${ }^{3}$, Mohd Fairuz Md Salleh ${ }^{4}$
}

$1 \quad$ PhD student, Centre for Contemporary Fiqh and Islamic Compliance, Faculty of Islamic Studies, National University of Malaysia (UKM) \& Lecturer, Kulliyyah of Sharia and Law, Sultan Abdul Halim Mu'adzam Shah International Islamic University (UniSHAMS), Malaysia

Email: cikmarina9@gmail.com

2 Associate Prof Dr., Centre for Contemporary Fiqh and Islamic Compliance, Faculty of Islamic Studies, National University of Malaysia (UKM), Malaysia

Email: shofian@ukm.edu.my

3 Senior Lecturer, Centre for Contemporary Fiqh and Islamic Compliance, Faculty of Islamic Studies, National University of Malaysia (UKM), Malaysia

Email: dahlan@ukm.edu.my

4 Senior Lecturer, Centre for Sustainable and Inclusive Development, Faculty of Economics and Management, National University of Malaysia (UKM), Malaysia

Email: fairuz@ukm.edu.my

\section{Article Info:}

\section{Article history:}

Received date: 30.01 .2020

Revised date: 02.02 .2020

Accepted date: 08.02.2020

Published date: 13.03.2020

\section{To cite this document:}

Abu Bakar, M., Ahmad, S., Salleh, A. D., \& Md Salleh, M. F. (2020). The Implementation of Good Governance in Sustaining Waqf Fund: An Experience of Indonesian Waqf Board (BWI). International Journal of Banking, Accounting, and Finance, 2 (2), 46-65.

DOI: $10.35631 /$ AIJBAF.22005.

\begin{abstract}
:
Good governance is at the heart of any successful organization. It helps the organization to achieve its objectives and drive improvement, as well as maintain legal and ethical standing in the eyes of shareholders, regulators and the wider community. The implementation of good governance builds a positive reputation and helps to increase business sustainability and profitability within the organization. Indonesia is the most populous Muslimmajority country in the world and has great potential in waqf assets and funds. Indonesian Waqf Board (BWI) is an independent state institution, formed based on Law Number 41 of 2004 concerning waqf. The main objective of its establishment is to become a coordinating institution of existing nazhir (waqf managers) in managing and supervising waqf assets and funds. This paper aims to critically analyze the implementation of good governance adapted by the Indonesian Waqf Board (BWI) in sustaining its waqf fund. A qualitative method approach was employed using primary and secondary sources. The primary data was collected through the interview session with BWI officers, while secondary sources were collected through published regulation and reports, journal papers, and articles. The content analysis approach was adopted to analyze the data gathered from this study. The findings showed that the Indonesian Waqf Board (BWI) was given huge responsibility by carrying
\end{abstract}


out various functions whether as a motivator, facilitator, regulator and other supporting roles. The huge responsibility and the overlapping functions of the BWI have pros and cons in sustaining its waqf fund. This study is expected to provide the current condition of waqf governance in Indonesia and the sustainability of waqf funds managed by the Indonesian Waqf Board (BWI).

Keywords:

Good Governance, Waqf, Indonesian Waqf Board (BWI), Sustainability

\section{Introduction}

The practice of donating property in the form of waqf is a religiously mandated order, but it is not required to prove that the devotees care about the public interest. In terms of its purpose and wisdom, it is clear that the practice of waqf is about the same as the practice of issuing other forms of zakat that are compulsory. The practice of waqf is also strongly influenced by one's level of faith and piety and has contributed greatly to the development of the history of Islamic civilization. Waqf has proven to be a prominent mechanism in the work of welfare, social, scientific and economic development because of its profound impact on the socioeconomic history of the nation. Compared to other charitable activities promoted by the Sharia such as charity and giving, waqf has proven to have a very special effect. These perpetual donations appear to be enjoyed and passed on from one generation to the next as the property used must be permanent, non-perishable and for sale. This caused the waqf to be performed by the waqf recipient for a lifetime reward and continued until after his death, as long as the waqf's property continued to be utilized. Given the importance of this waqf, it is imperative that the functions and roles of the nazir as managers, administrators and trustees are taken seriously. The role of the exorcist is not only limited to safeguarding waqf assets but rather generating or driving waqf assets towards the empowerment of those assets and ultimately these waqf assets and benefits will continue to be sustainable.

Indonesian Waqf Board (BWI) is an independent state agency established under the Law 41 of 2004 on waqf. This body was formed in order to develop and develop waqf in Indonesia. Based on BWI's work, the existence of the Indonesian Waqf Agency has a very strategic position in producing the waqf effectively. The establishment of the BWI aims to manage the waqf in an optimal manner, especially in relation to management as an example of managing local and international waqf assets that have not been developed and to help build a less competent naqf in managing waqf in Indonesia. BWI is independent, professional and synergistic with the role of government as regulator, facilitator, motivator and public service. Table 1 below shows data on the development of waqf land in Indonesia by province in 2017. Looking at the potential of waqf assets, BWI plays a significant role in preserving waqf property so that waqf benefits will continue to be enjoyable, lasting and sustainable for the Muslim community in Indonesia. This paper aims to analyze the governance practices implemented by BWI in maintaining waqf funds in Indonesia. 
Table 1: Waqf Land Data in Indonesia by Province in 2017

\begin{tabular}{|c|c|c|c|c|c|}
\hline \multirow{2}{*}{ Province } & \multicolumn{2}{|c|}{ Number of Waqf Lands } & \multicolumn{2}{|c|}{ Status } & \multirow{2}{*}{$\begin{array}{c}\text { Percentage } \\
\text { of Waqf } \\
\text { Land } \\
\text { Registered } \\
(\%)\end{array}$} \\
\hline & Location & Width $\left(\mathbf{H}^{2}\right)$ & $\begin{array}{c}\text { Already } \\
\text { Have Waqf } \\
\text { Certificate }\end{array}$ & $\begin{array}{c}\text { Do Not } \\
\text { Have } \\
\text { Waqf } \\
\text { Certificate }\end{array}$ & \\
\hline 1 Aceh & 24.898 & 76.78690 & 13,730 & 11,168 & 55.14 \\
\hline 2 North Sumatra & 16.280 & 3.603 .55 & 7761 & 8,519 & 47.67 \\
\hline 3 West Sumatra & 6.643 & 21.221 .24 & 4420 & 2,223 & 66.54 \\
\hline 4 Riau & 8.152 & 118.397 .65 & 2,641 & 5,691 & 32.40 \\
\hline 5 Jambi & 5.918 & 1.351 .67 & 3,785 & 2,153 & 63.95 \\
\hline 6 South Sumatra & 6.394 & 38.045 .62 & 3,521 & 2,873 & 55.07 \\
\hline 7 Bengkulu & 2.759 & 712.22 & 1,869 & 890 & 67.74 \\
\hline 8 Lampung & 14.591 & 2.299 .08 & 8,372 & 6,219 & 57.38 \\
\hline 9 Riau Islands & 1.187 & 106.58 & 326 & 861 & 27.45 \\
\hline 10 Bangka Belitung & 1.133 & 324.31 & 778 & 354 & 68.76 \\
\hline 11 DKI Jakarta & 7.422 & 301.36 & 4,623 & 2,799 & 62.29 \\
\hline 12 Banten & 20.089 & 3.932 .23 & 11.049 & 9,040 & 55.00 \\
\hline 13 West Java & 74.860 & 11.666.20 & 45,873 & 28,987 & 61.28 \\
\hline 14 Central Java & 103.294 & 16.316 .97 & 82,641 & 20,653 & 80.01 \\
\hline 15 DI Yogyakarta & 8.547 & 293.39 & 8,051 & 496 & 94.20 \\
\hline 16 East Java & 74.429 & 5.823 .93 & 54,193 & 20,236 & 72.81 \\
\hline 17 South Kalimantan & 9.265 & 1.255 .36 & 7,582 & 1,683 & 81.83 \\
\hline 18 West Kalimantan & 4.467 & 2.754 .44 & 2,257 & 2,110 & 50.53 \\
\hline 19 East Kalimantan & 3.423 & 1.398 .41 & 772 & 2,652 & 22.55 \\
\hline 20 Central & 2.642 & 577.85 & 1,631 & 1,011 & 61.73 \\
\hline 21 Bali & 1.399 & 1.399 .00 & 1,132 & 267 & 80.91 \\
\hline 22 West Nusa & 12.105 & 2.581 .18 & 7,031 & 5,074 & 58.08 \\
\hline 23 East Nusa & 1.272 & 531.18 & 1,047 & 225 & 82.31 \\
\hline 24 South Sulawesi & 10.440 & 102.903 .03 & 5,485 & 4,954 & 52.55 \\
\hline 25 North Sulawesi & 887 & 190.53 & 420 & 467 & 47.35 \\
\hline 26 West Sulawesi & 2.448 & 325.17 & 571 & 1,877 & 23.33 \\
\hline 27 Central Sulawesi & 3.173 & 16.504 .28 & 2,051 & 1,122 & 64.64 \\
\hline 28 South East & 2.386 & 522.60 & 1,516 & 370 & 63.54 \\
\hline 29 Gorontalo & 1.877 & 166.34 & 729 & 1,148 & 38.84 \\
\hline 30 Maluku & 1.215 & 500.64 & 449 & 766 & 36.95 \\
\hline 31 North Maluku & 1.489 & 3.022 .32 & 605 & 543 & 40.53 \\
\hline 32 West Papua & 338 & 59.11 & 105 & 233 & 31.07 \\
\hline 33 Papua & 346 & 69.45 & 142 & 204 & 41.04 \\
\hline Total & 435.768 & 435.944 .32 & 287,160 & 148,447 & 65.90 \\
\hline
\end{tabular}

Source: Indonesia Waqf Board (BWI)

\section{Literature Review}

\section{Waqf Administration in Indonesia}

\section{History of Waqf Administration in Indonesia}

Historically, the administration of waqf in Indonesia can be divided into three main periods; that is, before Indonesia's independence (before 1945), after Indonesia's independence and before Government Regulation No. 28 of 1977 and after the implementation of Government Regulation No. 28 Year 1 977. In fact, the waqf institution was already in existence and 
practiced by the Muslim community in Indonesia before Indonesia gained independence. Historical relics such as the Islamic sultanates for example the Demak sultanate and the Pasai Sultanate, the construction of mosques and mosques in Indonesia's central city are among the earliest evidence that waqf existed before 1945. At this time, waqf was administered by Customary Law issued by the Dutch Colonial Government. This law is an unwritten law and is not based on waqf law in Islam. There are some rules regarding waqf issued by the Dutch Colonial Government during his colonial period in Indonesia such as the first SecretaryGeneral's Circular dated January 31, 1905, No. 435, Circular of the Secretary of the Government dated 4 June 19311361 / A, Circular of the Secretary of the Government dated 4 December 19341361 No. 3088 / A and the Secretary of State Secretary's Circular dated 27 May 1935 No.1273 / A (Ministry of Religion of the Republic of Indonesia, 2004).

Then, after Indonesia's independence and before the establishment of Government Rule No. 28 In 1977, waqf was implemented in accordance with Article II of the Transitional Laws Act 1945. On December 22, 1953, the Religious Department of the Republic of Indonesia was established and placed all matters pertaining to waqf under the special powers of the use of waqf property. On October 8, 1956, Circular No. 5 / D / 1959 on Land Transfer Procedure issued. However, this procedure still could not fully protect the waqf lands at that time. This led to Government Regulation (PP) No. 28 of 1977 on Land Tenure Subdivision was subsequently issued. Existence of PP No. 28 of 1977 has repealed all the existing rules of waqf law and conflicts with the rules (Aden, R., Effendi, D. \& Busro, 2018). Next, the third phase is after the implementation of Government Rule No. 28 of 1977 or after the issuance of Law No. 7 of 1989 on Religious Justice. Through this law, Chapter III mentions the council assigned and entrusted to examine, decide and settle things on the first floor between people who are Muslims in the field; (a) marriage; (b) heirs, wills and grants, made in accordance with Islamic law (c) waqf and alms. However, these regulations have not yet been able to address the various problems related to waqf. On November 30, 1990, Directions with the Minister of Religion of the Republic of Indonesia and Head of the National Defence Agency (BPN) Number 4 of 1990 on Waqf Land Certificate were issued.

The transformation of waqf development in Indonesia can be seen on 2002, when an international workshop on productive waqf was held in collaboration with the International Institute of Islamic Thought (IIT) and the Ministry of Religion of the Republic of Indonesia held in Batam from January 7 to 8, 2002. The workshop was followed by a Seminar National Productive Waqf in Medan from May 1 to 2, 2002. In this seminar, a fatwa was issued that demanded cash waqf in Indonesia by the Council of Indonesian Scholars dated May 11, 2002 and a letter from the Ministry of Religion of the Republic of Indonesia. The development of waqf has been growing ever since the introduction of Law 41 of 2004 on waqf which is still used to this day as the main reference to waqf affairs in Indonesia.

\section{The Administration of Contemporary Waqf in Indonesia}

The administration of waqf in Indonesia today is enforced through law (Religious Department of the Republic of Indonesia, 2004). Some of the laws that apply to manage waqf governance in Indonesia are:

1. Agraria Law (UUPA), Law 51960 of chapter 5, article 14 paragraph (1) and article 49.

2. Government Regulation No. 28 The year 1977 consisted of 7 chapters, 18 chapters, covering the meaning of waqf, the procedure for interpreting and registering waqf, changes, dispute resolution and waqf authorities.

3. Registration of Religious Minister No. 1 The year 1978 describes in detail PP. 28, 1977. 
4. Inpres (Presidential Instruction) No. 19911991 Compilation of Islamic Law (KHI). KHI is the development and refinement of waqf arrangements in accordance with Islamic law.

5. About the Laws of the Foundation. The designation of this foundation is contained in Law No. 16 Year 2001 dated 16 August 2001 LN Year 2001 No. 112.

6. SK (Letter of Authority) Dir. BI No. 32/34 / KEP / DIR About Public Bank Based on Sharia Principles.

7. SK (Letter of Authority) Dir. BI No. 32/36 / KEP / DIR About People's Banking Credit Based on Sharia Principles.

8. Law No. 41 of 2004 on waqf.

9. Government Code No. 42 of 2006 on the Implementation of Law No. 41 of 2004.

10. Presidential (Presidential Decree) of the Republic of Indonesia 75 / M / 2007 on the establishment of an institution called the Indonesian Waqf Agency (BWI).

11. Regulation of the Religious Ministers of the Republic of Indonesia No. 4 of 2009 on Waqf Registration Administration.

\section{Indonesian Waqf Board (BWI)}

\section{History of Establishment of Indonesian Waqf Board (BWI)}

The Indonesian Waqf Body (BWI) is an independent state agency established under the 414 Law of the Year 2004 on waqf. This body was formed in order to develop and develop waqf in Indonesia. The BWI was established not intended to take over the waqf assets that are currently managed by the nazhir (asset manager for waqf). On the other hand, the BWI plays an important role in developing the nazhir so that waqf assets can be managed more efficiently and more efficiently so as to provide greater benefits to the community which includes social aspects, economic empowerment and public infrastructure development. BWI is based in the state capital and has several representatives in each province, county, and / or city according to existing requirements. BWI members are appointed and terminated by the President. The term of service is 3 years and may be reappointed within a period of service. The number of BWI members is 20 to 30, while the appointment of BWI members during the first term of service is proposed by the Minister of Religion to the President. Then, for the next term of service, it is proposed by the Selection Committee formed by BWI. Meanwhile, BWI representatives were appointed and terminated by BWI. The organizational structure of the BWI consists of the Board of Considerations and the Board of Directors. Each was led by a Chairman chosen from among the BWI members. The Implementing Body is responsible for carrying out waqfrelated tasks, while the Board of Appeals plays the role of supervisor (Indonesian Waqf Board, 2019).

\section{Authority, Duties and Responsibilities of the Indonesian Waqf Board (BWI)}

The vision, mission and strategy of Indonesia's BWI is to create an independent institution that is trusted by the Indonesian community, capable and integrated in developing waqf nationally and internationally. BWI's mission is to make BWI a professional institution capable of realizing the potential and economic benefits of waqf property for the benefit of waqf worship and empowerment of the people in Indonesia. Among the strategies used by BWI in expanding waqf management are to increase national and international competencies and networks, formulate waqf-related regulations and laws, increase desire and awareness among Indonesian people to practice waqf, enhance professionalism and nazhir trust in management and developing waqf assets, coordinating and building human development for the entire nazhir waqf, organizing governance for waqf assets and collecting, managing and developing national and international waqf assets. 
In accordance with Article 49 Section 1 of Law 41 of 2004 on waqf, BWI has the following main duties and responsibilities; First, build on the nazhir in the management and development of the waqf property. Second, carry out national and international waqf property management and development. Third, give consent and or consent to changes in the provisions and status of the property waqf. Fourth, terminate the service and appoint a nazhir. Fifth, give consent to the case of exchange of property waqf. Sixth, provide the Government with suggestions and consideration for the preparation of laws in the field of waqf in Indonesia. Then, under the BWI Regulation No. 1 of 2007 on the Organization and Functions of the Waqf Indonesia Agency, BWI performs its duties and responsibilities as follows; a) Developing the naqhir in the management and development of waqf property, b) Developing the management and development of waqf property, c) Performing national and international waqf property management and development as well as undeveloped waqf properties, d) Provide consideration, agreement, and / or consent to changes in the provision and status of waqf property, e) Provide consideration and / or consent to the transfer of waqf property, f) Provide advice and consideration to the Government in drafting legislation in the field of law, g. ) Receiving, evaluating, administering nazhir registrations, and resuming expired nazhir services, h) Ending services and replacing nazhirs as needed, i) Providing recommendations and consideration to the Minister of Religion in assisting the Syariah Finance Authority Waqf Money (LKS) -PWU), j) Received the Waqf Pledge Registration Act (AIW) objects other than cash waqf from the Waqf Pledge Act Office (PPAIW).

In carrying out its duties and responsibilities, BWI has worked with the Ministry of Religion (Waqf Empowerment Directorate), Indonesian Council of Scholars, National Defence Agency, Bank Indonesia, National Development Planning Agency, Islamic Development Bank, and many other agencies. In some cases, BWI also collaborates with entrepreneurs / investors in order to develop waqf assets to be more productive. However, in order to assist in the implementation of BWI's duties and functions, BWI established representatives (branches) at the provincial and district levels. In accordance with the jurisdiction granted in the law, BWI may form a Provincial BWI Representative or a BWI District / City Representative. Formation of BWI representation was proposed to BWI by the Regional Head of the Ministry of Religion and the Head of the Ministry of Religion. The organizational structure of the BWI Representative consists of the Board of Considerations and the Board of Directors. The Implementing Council is an oversight element of the implementation of the Implementing Agency's tasks. The BWI Representative is made up of 14 people. A total of 3 are on the Judiciary Council and 11 are on the Executive Board. All members of the Council of Judiciary and the Executive Body are from the Ministry of Religion, the local government, the Indonesian Council of Scholars, scholars, nazhirs, legal experts and entrepreneurs. Membership of BWI representatives is appointed and terminated by BWI. As of October 2019, BWI has 34 Representatives at Provincial level throughout Indonesia. The division of duties and jurisdiction of BWI, Provincial BWI Representative and District / City BWI Representative are depicted in Table 2 below. Meanwhile, the Board composition of Indonesian Waqf Board (BWI) for year 2017 until 2020 is shown in Figure 2. 
Duties and Jurisdictions

\section{District/City BWI Representatives}

1. Carry on nazhir construction andImplement BWI policies and Implement BWI policies management of waqf property. duties at the provincial level. ${ }_{\text {and duties at the district / }}^{\text {city level. }}$

Coordinate work with RegionalCoordinate the duties of the Performs national andReligious Offices of the MinistryMinistry of Religious

2. international waqf propertyof Religion and relatedOffices and related management and development. institutions in carrying out theirinstitutions in carrying out duties. their duties.

Provide consent and or permission

3. to changes in the allocation and Appoint nazhir in managing andAppoint nazhir in managing status of the property waqf. developing the waqf.

Terminate the nazhir service and Act and be responsible on behalf of Act and be responsible on BWI Provincial Representatives, ,Rehalf of BWI District/City appoint the nazhir. both internally and externally. internally and externally.

Terminate and / or replace theTerminate and / or replace

5. Agree on the case of exchange ofnazhir of waqf land which isthe nazhir of waqf land property waqf. 1,000 square meters to 20,000 whose area is less than 1,000 square meters. square meters.

Provides advice and considerationTo produce proof of registration

6. to the Government in drafting theof waqf land covering 1,000 law in the field of waqf insquare meters up to 20,000 square waqf land with an area of less Indonesia. meters. than 1,000 square meters.

Conduct at least 1,000 squareConduct at least 1,000 7. - $\quad$ proposed for change orsurvey proposed for change meters of waqf land surveysquare meters of waqf land conversion and reports theor conversion and report results to BWI. results to BWI.

8.

Perform other tasks assigned by Perform other tasks BWI. assigned by BWI Provincial representatives. 


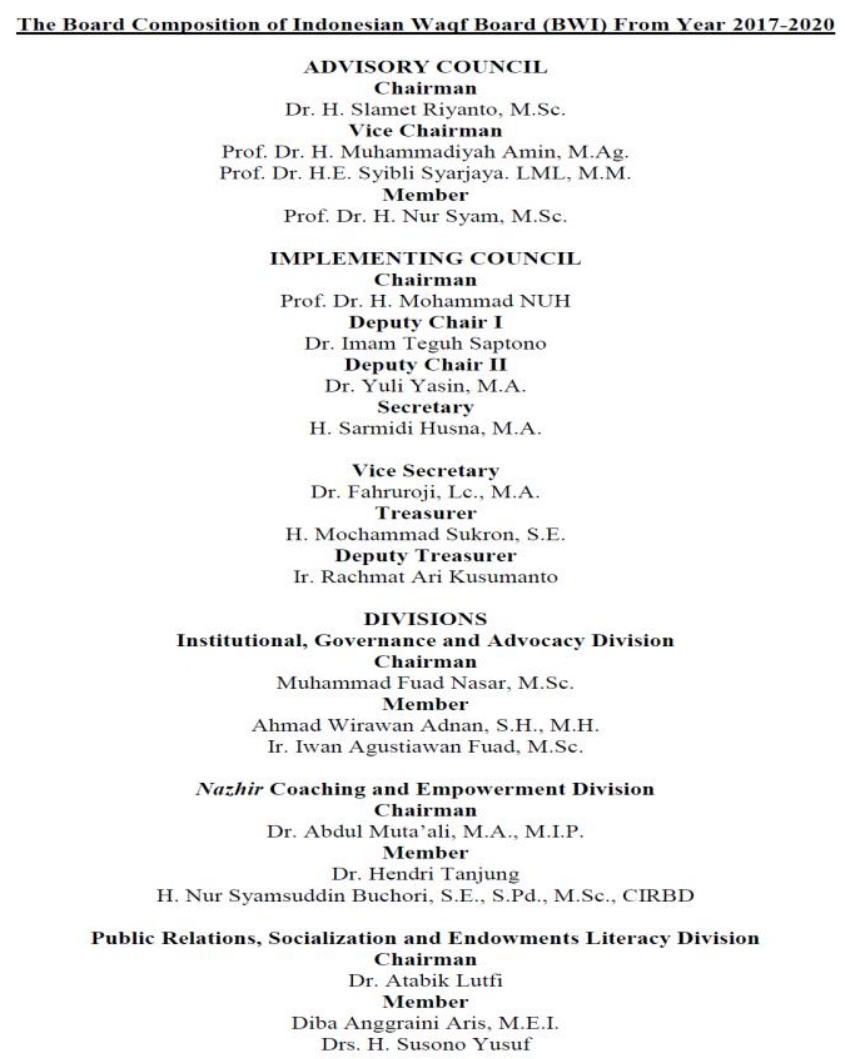

Figure 2: The Board Composition of Indonesian Waqf Board (BWI) Year 2017-2020 Source: Indonesian Waqf Board (BWI)

\section{Implementation of Cash Waqf in Indonesia}

In the Indonesian context, there are several institutions related to the implementation of cash waqf in Indonesia. Among these institutions are the Ministry of Religion (KEMENAG), Indonesian Waqf Board (BWI) and Waqf Money Receiver Shariah Finance Authority (LKS PWU). KEMENAG is the highest institution representing the Indonesian government in dealing with matters related to religious matters in Indonesia, including waqf matters that are placed under the authority of the Waqf Empowerment Division, Director General of Islamic Community Guidance. The main task of the Ministry of Religion is to formulate rules and regulations relating to cash waqf. BWI is a national institution that is specially created and independent in the administration of public waqf in Indonesia. However, in matters of cash waqf, BWI is responsible for monitoring, monitoring and determining any policies or policies related to the implementation of cash waqf in Indonesia. LKS PWU is a special entity set up by the Indonesian government to administer cash waqf and to implement the cash waqf policies practically.

At the time BWI was established around 2007, cash waqf practices were not yet developed in Indonesia. Although BWI is the main trustee of waqf administration in Indonesia, at the time, BWI did not have an official nazhir administering cash waqf in Indonesia. The main factor in the absence of official sanctions is that the BWI is required to await a decision from the Minister of Religion of the Republic of Indonesia for the process of verifying cash waqf and administering cash waqf through the names of the PWU LKS even though the Council of Indonesian Scholars (MUI) has issued a ruling calling for cash waqf in Indonesia 6 years ago. By Decree of the Religious Minister of the Republic of Indonesia 92-96 of 2008, five institutions were selected as PWU LKS namely Bank Muamalat Indonesia, Bank Shariah Independent, BNI Shariah, DKI Shariah Bank and Shariah Mega Bank. Then, in 2010, the 
Minister of Religion of the Republic of Indonesia added two more banks as members of the PWU LKS, namely Shariah Bukopin Bank and Shariah BTN. As of 2019, there are 12 banks that have been appointed as PWU LKS by the Minister of Religion of the Republic of Indonesia including Regional Development Bank (BPD) Jogja Shariah, District Development Bank (BPD) West Shariah, Regional Development Bank (BPD) Shariah, Development Bank Riau Shariah District (BPD) and Shariah Jatem District Development Bank (BPD).

\section{Productive Waqf in Indonesia}

Productive waqf can be defined as a form of waqf management oriented towards the productive sector. The main focus is on how the assets of waqf can be developed and in turn produces sustainable profitability and benefit the socio-economic aspects of Muslims. In managing productive waqf in Indonesia, BWI has implemented 3 key concepts for the development of waqf assets; that is, the first; develop waqf assets in the form of immovable property such as land to waqf assets in the form of capital such as waqf shares, secondly; expanding existing waqf assets through management according to current and third socio-economic trends; expanding waqf benefits to more and more beneficiaries not only for the poor and needy, but also for the use of places of worship, social, human resource development, education and research scholarships and more. (Zaenal, M.H., 2017). Figure 2 below illustrates the percentage breakdown of waqf benefit distribution issued by KEMENAG till 2019 representing various sectors. The divisions involved were mosques (44.56\%), surau (28.7\%), schools $(10.65 \%)$, social $(8.60 \%)$, cemetery $(4.49 \%)$ and boarding schools $(3.42 \%)$.

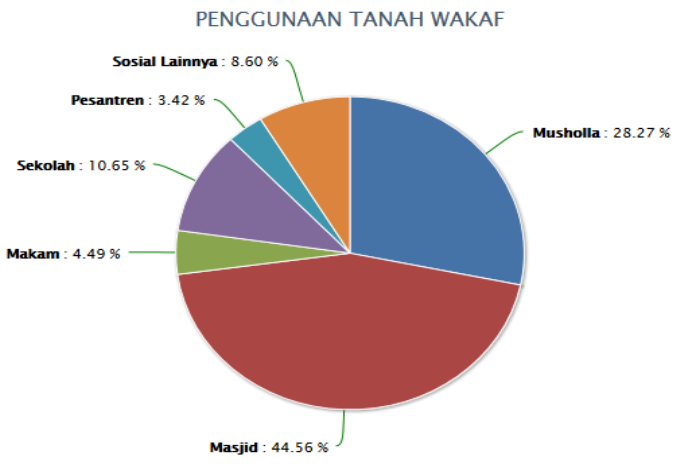

Figure 1: Distribution of Waqf Benefits in Indonesia until 2019

Source: Kementerian Agama Republik Indonesia (KEMENAG)

Although Indonesia has enormous waqf potential, it is still restricted to traditional forms such as cemeteries, mosques and boarding schools (Ikhsanudin, M., 2012). There are many undisputed waqf potentials for the socio-economic development of Muslims in Indonesia. Lately, there have been many productive waqf projects being undertaken in Indonesia either through the government or the private sector. BWI represents the government of the Republic of Indonesia and also actively administers several waqf projects in Indonesia. Among the most popular are cash waqf and Bank Waqf Ventura. The private sector has also implemented several waqf projects in Indonesia, including through the Indonesian Waqf Fund (TWI) which is owned by the Dompet Dhuafa Republika Indonesia Foundation. 


\section{Cash Waqf by LKS PWU}

Cash waqf is one of the earliest contemporary forms of waqf introduced in Indonesia. Establishment of PWU LKS is contained in the Government of the Republic of Indonesia (PP) No. 42 of 2006 regarding the Implementation of Law No. 41 of 2004 on waqf in Paragraph 3, Article 2. Through the provisions of this law, the function of the PWU LKS is to provide information to the public about its existence as a Shariah Cash Receipt Authority (LKS PWU), providing a Cash Waqf Certificate (SWT) form for people who want to provide cash, receive cash waqf money from the waqf lender in the name of waqf nazhir, put cash waqf into account deposit (wadi'ah) in the name of the nazhir appointed by the waqf, accept the statement of waqf's wishes in writing in the statement of waqf's will, issue the SWT and submit the certificate to the waqf and to the nazhir appointed by the waqf giver and register the cash waqf to the Minister of Religion in the name of nazhir. The provisions on cash waqf are also clearly set out in Article 22 of the Government Regulation 42 of Year 2006. Under this provision, there are several conditions to be followed in the implementation of the cash waqf, which must be in the form of Rupiah, if the currency is not in the form of Rupiah, then it must be converted into the currency of Rupiah and the waqf who intends to perform the waqf are required to attend the PWU LKS to prove several things including the intention of the waqf, the ownership and origin of the money to be paid and the money handed over to the PWU LKS. In addition, waqf issuers are also required to fill out a statement of intent to commit waqf which functions as the Waqf Pledge Act (AIW). The waqf must be referred to the nazhir before the Office of the Wakaf Pledge Act (PPAIW). Finally, the nazhir will hand over the AIW to the LKS PWU.

In distributing cash waqf funds, PKSU works as a nazhir. Therefore, the PWU LKS will hold a meeting and discuss with the BWI. This is because BWI is the only party with full authority over the management and administration of money waqf in Indonesia. BWI will also discuss with the Ministry of Religion of the Republic of Indonesia (KEMENAG) on the management and distribution of cash waqf funds. Upon mutual agreement from BWI, PKSU will manage and distribute waqf funds to several development and investment projects. The proceeds from these projects are distributed to beneficiaries and to the benefit of Muslims. The PWU worksheet divides the cash waqf fund into 2 main categories, namely taslim and tawzi'. The taslim fund refers to the funds raised from the waqf donor through the cash waqf to the waqf giver account managed by the LKS PWU. LKS PWU comprises of banks appointed by the Minister of Religion of the Republic of Indonesia to collect cash waqf. This fund is made up of principal or waqf principal. Therefore, its value must be maintained and should not be reduced in accordance with the law of waqf in Islam. This is because waqf literally means tying up of an asset (whether in a form of real estate, cash etc) for some specific Sharia-compliant objectives in such a way that the 'asl (principle) remains intact and only its $r e$ 'a (usufruct) is spent on the named objectives. Meanwhile, tawzi' funds refer to funds derived from waqf development or investment projects that have been carried out. The proceeds from this waqf tawzi' will be utilized for the benefit of the community including education, health, social and so on. Generally, while awaiting full and sufficient funds for investment projects, the bank (LWP PWU) will invest the cash waqf in the form of a brief investment under the supervision of BWI. Distribution of funds for the purpose of financing waqf projects also needs approval from BWI as the main trustee of waqf in Indonesia. Once invested in waqf projects, the proceeds of this investment will be put into the tawzi' fund. These funds will be distributed for the benefit of the benefit and the benefit of the ummah or invested again for the financing of the new waqf project. 


\section{Ventura Waqf Bank}

The Ventura Waqf Bank project has been a joint initiative between BWI, KEMENAG and international Islamic agencies since 2013. The concept of Ventura Waqf Bank is an adaptation of the waqf bank model in Bangladesh called Social Investment Bank Limited (SIBL). This adaptation is significant because Indonesia is said to have some similarities with Bangladesh, in terms of the Muslim population as the majority of the population apart from both countries have poverty problems. The main source of finance for the Ventura Waqf Bank is from cash waqf and land donated by waqf giver. Waqf giver will get cash waqf certificates from waqf banks worth around \$ 21 or less as per practice at SIBL Bangladesh (Zaenal, M.H., 2017). These waqf banks will be placed under BWI supervision and will receive bank operating funds through the budget under KEMENAG. Ventura Waqf Bank will be monitored periodically by BWI and KEMENAG.

To put it in perspective, the role of the Ventura Waqf Bank is as nazhir, as it starts with the process of collecting cash waqf, managing cash waqf and distributing waqf benefits. In fact, the waqf giver will also receive the waqf certificate issued by the waqf bank itself. To ensure that the value of the principal or principal waqf remains constant and does not diminish, a guarantor board is created and cooperated in managing the waqf fund. However, until 2019, the Ventura Waqf Bank project is still unrealized and is underway in Indonesia for several issues (Ventura Waqf Bank, 2017). Among these issues is the dilemma of Sharia banking institutions in managing waqf as nazhir. The role of the Sharia banking institution is contrary to that outlined in waqf law in Indonesia, where the administration, management and expansion of waqf should be performed by the nazhir, and the sharia banking institution is not included as the nazhir (Hukum Online, 2017). In addition, political influence also influenced the implementation of Ventura Waqf Bank as the idea of establishing a waqf concept bank was something new and has never been implemented in Indonesia so far (Havita, G., Sayekti, K. A., \& Wafiroh, S. R., 2014).

\section{Indonesian Waqf Fund (TWI) by Dompet Dhuafa Republika Foundation}

The Dompet Dhuafa Republika Foundation has been listed in the Ministry of Social Affairs of Indonesia as a Foundation-based organization under the Notary $\mathrm{H}$. Abu Yusuf, SH on September 14, 1994. In reference to Indonesian Law No. 41 of 2004 on waqf, the Dhuafa Republic wallet Foundation has registered with Waqf Indonesia Council as nazhir on June 16, 2011 with registration number 36.74.3.1.00001. The Dompet Dhuafa Republika Foundation then formally established the Indonesian Waqf Fund (TWI) on July 14, 2005. Among the main missions undertaken by Dompet Dhuafa are the development of social programs and economic empowerment based on productive waqf. As of 2019, Dompet Dhuafa has managed to administer 58 waqf assets and carried out 6 new projects from the cash waqf collection made by the Indonesian community (Dompet Dhuafa, 2019). Although the Dompet Dhuafa Republika Foundation is a private institution, it is still regulated by BWI and KEMENAG. Table 3 shows the list of productive waqf asset projects carried out until 2019: 
Table 3: List of Productive Waqf Projects by Dompet Dhuafa Republika Foundation until 2019

\begin{tabular}{l}
\hline No Waqf Projects \\
\hline 1. $\begin{array}{l}\text { Sengon Sentul Bogor } \\
\text { Gardens }\end{array}$
\end{tabular}

2. Wisma Muallaf

3. SMART Cibinong School

4. Al-Syukro Universal Islamic School
Details

Given by Oediono Adiwisastro on February 1, 2005.

Location: Gunung Batu, RT 001 RW 08. Bojong Koneng Village, Babang Madang, Sentul Selatan, West Java.

Land Area: $15.000 \mathrm{~m}^{2}$.

It is a joint project between Indonesia Waqf Fund (TWI) and PT Mitsubishi Electric to produce waqf land.

It started with the project of planting 1,000 sengon trees on November 3, 2012 and by 2019, 3,000 sengon plants were planted in the orchard.

Given by Ibu Djasrita Alamsyah on February 13, 2006.

Location: Desa/Kelurahan Pondok Pucung, Kecamatan Pondok Aren Bintaro, Kabupaten Tangerang, Banten.

Land Area: $306 \mathrm{~m}^{2}$

This is one of the Dompet Dhuafa programs that was developed to keep the family away from his family. In this place, the muallaf will be exposed to religious knowledge and Islamic law.

Wisma Muallaf started operations on August 31, 2008 and up to 2019, has already helped more than 700 muallafs in Indonesia.

SMART Cibinong School offers education ranging from TK (kindergarten), SD (primary) to SMP (high school) with a total student population of 808 students.

Given by PT. Holcim Indonesia on August 23, 2011.

Location: Jl. Raya Narogong Cileungsi, Klapanunggal, Bogor 16825

Land Area: $18.477 \mathrm{~m}^{2}$

Al-Syukro Universal Islamic School offers education from TK (kindergarten), SD (elementary) to SMP (high school) with a total student population of up to 845 students.

Given by Ibu Dra. Hj. Buli Oskar Surjaatmadja and family on November 22, 2010.

Location: Jl. Otista Raya. Gang H. Maung, Cipayung, Ciputat, Tangerang, Banten.

Land Area: $27.523 \mathrm{~m}^{2}$

Building Area: $5.373 \mathrm{~m}^{2}$ 
5. Bumi Pengembangan Insani (Human Development)
There are several educational programs by Dompet Dhuafa such as SMART Indonesia Ekselensia Schools, ETOS Scholarships, Learning Centers, SGI (Indonesian Teachers' Schools) as well as Training and School Assistance on Earth Human Development. SMART Ekselensia Indonesia is a boarding school set up for people with disabilities. It is a free school with a 5 year system for elementary and high school. It began operating in 2004 and has now completed the education of 245 students.

ETOS Scholarships are scholarships for new students at PTN (State Colleges), beginning in 2003 and to date have been used by 5480 students from all over Indonesia.

Indonesian Teacher School is a school aimed at graduates who intend to become teachers with a one-year teaching period, beginning in 2010 and now producing 1054 teachers.

Training and School Assistance is a program to improve and develop the ability to teach teachers in remote schools and to help school management improve the quality of education. Starting in 2004 and through 2019, the School Training and Assistance program has provided training for 18,057 teachers and 337 mentoring schools. Given by waqf givers on Mac 1, 2004.

Location: Jl. Raya Parung Bogor KM 42 Desa Jampang Kec. Kemang, Bogor 16310.

Given by Ibu Zahro Lamruni on November 21, 2016.

Location: Jl. Peninggilan Utara, Ciledug, Tangerang

Land Area $286 \mathrm{~m}^{2}$

Building Area: $88 \mathrm{~m}^{2}$

Total: 4 Stores

The waqf surplus a year is Rp100.000.

Given by Bapak Agus Murdijanto on May 25, 1999.

Location: Jl. Keadilan No. 13 RT. 02 RW. 04 Bhaktijaya, Sukmajaya, Depok

7. Unit Kedai Keadilan Depok $\begin{aligned} & \text { Land Area: } 248 \mathrm{~m}^{2} \\ & \text { (Shop Unit) }\end{aligned}$
Building Area: $496 \mathrm{~m}^{2}$

Unit Kedai Keadilan Depok has two floors. The first floor has one large store with a rent of Rp33.000.000 a year and two small units for a rent of Rp10.000.000 a year. Meanwhile, the second floor is rented for Rp25.000.000 a year.

Given by waqf givers via Dompet Dhuafa and launched on October 11, 2013.

Location: Jl. Raya Parung Bogor KM 42 Desa Jampang Kec.

8nit Kedai
(Shop Unit)

aKemang Bogor 16310

Land Area: $999 \mathrm{~m} 2$

It consists of 6 shop units, 2 floors for a rent of Rp80.000.000 a year. Unit Kedai Zona Madina has been leased since September 26, 2014 and up to 2015 has generated Rp400.000.000 waqf surplus. 
Given by Ibu Amir Batubara on April 15, 2010.

Wardah Mall:

On the 1st floor, there are rooms that can accommodate up to 80 people, at a cost of Rp800.000 ( 8 hours). On the second floor, there are 3 small rooms with a capacity of 25 people, renting for Rp500.000 (8 hours). 9. Gedung WTMC \& Gedung Location: Kompleks Perum Villa Ilhami Islamic Village. Jalan

Zaitun Raya, Karawaci Kel. Kelapa Dua Kec. Curug Tangerang Banten.

Jannah Mall:

The building is leased by the Institute for Independence at a cost of Rp150.000.000 a year. Until 2019, the proceeds of this building generate a waqf surplus of Rp533.000.000.

The Philanthropy Building consists of 5 floors. It was the first building owned by Dompet Dhuafa waqf-based. He was hired as the

10. Gedung

Kilang Ekstrak

11. Indonesia Berdaya (Powerful Indonesian Extract Factory)

12. Khadijah Learning Centre

13. Al-Madinah Mosque
Philanthropymain office of the Dompet Dhuafa Foundation for rent of 1-3 floors of Rp215.000 floor 4-5 for Rp165.000, including service costs.

Until 2019, the waqf benefit of this building has been making a surplus of Rp1.371.798.500 a year.

Dompet Dhuafa through the Powerful Indonesia program has modified 8.5 hectares of land by planting a variety of fruit trees in Subang, West Java. Among the fruits grown are dragon, pineapple, papaya, crystal and avocado.

The Fruit Garden is managed with a plasma core system. Although the land is owned by Dompet Dhuafa, for the purpose of increasing Buahthe production of fruit, the people of the surrounding area are also encouraged to grow the same fruit which will be purchased by FruitDompet Dhuafa at a profitable price to farmers.

In its planning, Dompet Dhuafa also wants to build a fruit extraction plant and processed foods (jam, syrup etc.). The plant is expected to produce labor intensive labor and hire labor from the poor. This is one of the productive forms of waqf, in which Dompet Dhuafa's land and cash donations can be a productive source of economic benefits for the poor.

The Khadijah Learning Center (KLC) is an informal educational institution with a mission of increasing girls' competence. The presence of the Khadijah Learning Center (KLC) is the Dompet Dhuafa's mission to produce entrepreneurial figures such as Khadijah r.a (wife of the Messenger of Allah). In this Khadijah Learning Center (KLC) education program, participants will participate in entrepreneurship training and workshops as well as acquire Islamic spiritual knowledge and guidance.

Al Madinah Mosque is one of the Dompet Dhuafa icons built in Madina Zone, Parung- Kabupaten. Bogor. It is not only for prayers, but the mosque was also built as a center of social activity propagation of Islam. In addition, the mosque comprises a 3 storey building with an area of $2830 \mathrm{~m} 2$. The entire mosque can accommodate more than 1500 members. In addition, the mosque is also equipped with a meeting room for various activities. This room can accommodate up to 800 people. 
14. SMART Mosque,
Cibinong School

15. Klinik Pratama Gera
Madiun

16. Klinik Naura Medika

This mosque is located on waqf land owned by Dompet Dhuafa, which previously had the Dompet Dhuafa SMART School building. The SMART Mosque is a complement to the school building in shaping the SMART community, students and teachers. The

SmartSMART Mosque is also expected to be a catalyst for community activities for the local community to create a harmonious atmosphere by reviving Islamic values, between the school community and the surrounding community. The SMART Mosque will also be a modern mosque equipped with micro library and support facilities for modern knowledge.

Location: Desa Rejosari, Kecamatan Sawahan, Kabupaten Madiun, SehatEast Java.

Given by Bapak Parni Hadi, on May 2, 2017. Land Area: $900 \mathrm{~m}^{2}$.

Location: Jl. Kemakmuran Raya No. 37 RT. 001 RW. 004 Kelurahan Mekar Jaya Kecamatan Sukmajaya Kota Depok.

Given by Bapak Sarman Muhammad Sidik, on November 18, 2017. Land Area: $569 \mathrm{~m}^{2}$

Building Area: $140 \mathrm{~m}^{2}$

Establishment of Sribhawono AKA Medical Hospital, in Sribhawono District, East Lampung Regency is part of the Dompet Dhuafa hospital network program. Dompet Dhuafa wants to build 17. Hospital Aka medika many hospitals in the area to serve the poorer people. Sribhawono
AKA Medical Hospital is set up with a total of 80 beds with the latest equipment such as labs, radiology and surgery.

Until 2019, The hospital has been a reference point for many health clinics and public clinics not only in the Sribhawono District, but also from the district adjacent to the Sribhawono District.

Integrated Hospital (RST) by Dompet Dhuafa is a hospital that specializes in serving the poor. In operation since 2012, the Integrated Hospital Rumah SehatHospital has been developed and managed with the support of Zakat, 18. Terpadu (RST) DompetInfaq, Charity, Waqf and Islamic Philanthropy (ZISWAF) funds. As Dhuafa of 2019, the total area of the Integrated Hospital building is 7,803 $\mathrm{m} 2$ and has been able to provide assistance to over 15,000 poor people.

Source: Dompet Dhuafa Republika Foundation.

\section{Analysis of Indonesian Waqf Board (BWI) in Sustaining Waqf Funds in Indonesia}

The Enactment of Law 41 of 2004 has made a positive impact on Indonesia's waqf management system to be more professional and independent. For this reason, a new institution with the ability and capacity to develop waqf assets in Indonesia needs to be more productive. The importance of establishing an independent national waqf board is needed to assist the nazhir in managing and developing waqf assets nationally and internationally. BWI has been established in response to the development of professional management in Indonesia to produce the benefits of waqf that can promote the people of Indonesia. BWI plays a leading role in managing waqf governance in Indonesia because in addition to serving as nazhir, BWI is also a trustee of all waqf assets and funds as well as managing and developing it in a more productive framework. However, the role and competence of BWI in developing this waqf remains unclear. In fact, BWI has been given a great responsibility to revitalize waqf institutions throughout Indonesia by performing various functions as a motivator, facilitator, 
regulator and a number of other supporting roles. The huge responsibilities and overlapping functions of BWI have several advantages and disadvantages (Aslam, M. M. H., Kamil, M. N. K., \& Ayuniyyah, Q., 2017). BWI's efforts in administering and streamlining waqf development in Indonesia are seen as having a positive impact on the waqf sector across the country. However, it is important to note that there are many suggestions, both within and without the BWI, on the need to restore waqf governance in Indonesia, and this clearly indicates that waqf governance led by BWI cannot achieve the goals they are aiming for. The BWI should take various steps to change the existing governance tradition including paradigm shifts, regulatory strengthening, human resource strengthening and immediately initiating pilot projects to significantly enhance waqf development in Indonesia.

Indonesia has the largest Muslim population in the world. According to data from Global Religion, Indonesia's population in 2010 was 209.12 million Muslims or $87.17 \%$ of the total population reaching 239.89 million. By 2020, the Muslim population in Indonesia is expected to grow to 263.92 million and then increase to 256.82 million by 2050. (Global Religion Report, 2019). With this large number of Muslims, there is a great potential in the field of waffles either involving cash or land. According to KEMENAG, the total area of waqf land in 2017 was 435, 944.32 hectares (KEMENAG, 2019). However, 95\% of this waqf land is not well managed so it can provide optimum benefits. BWI also took a long time to collect cash waqf although the collection process had already been distributed to waqfs nazhir throughout Indonesia registered under BWI. From the total cash waqf collection from 2009 to 2018, BWI raised a total of Rp.193, 144, 957, 611 with a total of 88,673 waqf givers throughout Indonesia.

BWI's inability to provide a clear picture of the waqf scenario in Indonesia, especially in terms of total waqf assets nationwide for the current fiscal year 2019, makes the waqf's potential unexplainable. In fact, to date no survey has been conducted. Although recent studies have mentioned the great potential of Indonesian waqf assets, there is no accurate data to date. Of course, many stakeholders want to know their true potential if they want to work together and collaborate with BWI. According to Nani Almuin (2019), logistics issues are a major obstacle for the BWI to find the waqf data in Indonesia. The vast geography of Indonesia's and surrounded by mountains and islands makes the quest for data difficult. The BWI also does not have sufficient funds to hire a professional land surveyor to measure waqf lands in remote areas (Nani Almuin, 2019).

Although the majority of Indonesian people are Muslims, there is still a lack of awareness and knowledge of the Muslims themselves regarding waqf worship. The Muslim community in Indonesia generally recognizes the waqf limited to traditional forms such as land, mosque, and cemeteries. This is evidenced by the percentage of distribution of waqf benefits in Indonesia until 2019, of which only $8.60 \%$ is distributed for social use (KEMENAG, 2019). BWI is also facing a major challenge in managing its registered bishops. Based on a study conducted on 21 waqf lands in Jakarta, Indonesia in 2016, BWI found four types of waqf institutions in terms of assets and potential that could be developed into productive waqf (Indonesian Waqf Board, 2016). The first is a nazhir with large and potentially high waqf assets such as the Darul Azkar Foundation and the Husnayain Foundation. Secondly, nazhir waqfs have large waqf assets, but they are insufficient for the nazhirs such as the Hidayatullah Paypal Foundation, Al Birru Mosque Foundation, and Al-Barkah Mosque Foundation. Third, the waqf nazhir has small but high potential waqf assets such as the Baqurrahman Mosque Waqf Foundation, the Nur Assailina Foundation and the Al-Abrar Mosque Waqf Foundation. Fourth, nazhirs that do not have waqf assets or any potential cause the waqf institution does not allow them to be as productive as the Darussalam Al-Amin Mosque Waqf Foundation and the Al-Muflihun 
Mosque Foundation. The different categories of nazhirs representing the waqf institutions registered under the BWI led the BWI to use different approaches in helping them manage their funds and develop the waqf lands in Indonesia.

However, in terms of cash waqf management, BWI has appointed LKS PWU as nazhir. The BWI's move to appoint the PWU LKS as a nazhir has several advantages as the LKS PWU involves several Shariah banking institutions in Indonesia. On the one hand, it helps the cash process of the cash waqf fund. LKS PWU invests short, medium- and long-term investments to develop existing cash flows and is managed professionally, reliably and transparently, as well as acting as a shariah guarantor of cash waqf funds provided through the wadi'ah system (Zaenal, M. H, 2017). Short-term investments are like micro-credit investments. Banks have experience in working with governments for micro lending such as (BI) Small and Medium Enterprises by Indonesia Bank, medium term investments such as investments involving industries or small businesses. Bank Indonesia (BI) also provides several credit schemes for this type of investment. Thus, banks involvement in long-term investments, large industries and other manufacturing industries. Banks should have experience in making long term investments such as investments involving farms and factories as they are able to collaborate and collaborate with other banks to make large investments and profits.

In the era of the Industrial Revolution 4.0, BWI also had to study waqf in the digital age, especially those who used innovation and technology to unlock the waqf potential in Indonesia more optimally. Technology and digitization will revolutionize everything, including waqf. The use of block chain waqf is seen as very relevant in this era. Some countries and institutions have investigated the potential of block chain in various sectors, including waqf. Finterra, a Singapore-based financial technology company, has developed a crowdfunding platform that uses block chain to create smart contracts that are tied to waqf projects in Singapore and Malaysia (Kapital, 2019). Block chain is a breakthrough in financial technology that contains financial information that can be used for transactions, contracts, assets and identities that are fixed, transparent and easy to use. In addition, block chain is said to be capable of preventing any fraud or misappropriation and even this digital ledger can also be monitored by a community known as nodes. These nodes, in turn, play an important and powerful role. If this community does not agree to any changes, then no changes can be made. In fact, hackers are also difficult to manipulate any block chain data. Based on these advantages, Finterra is convinced to leverage this financial technology to manage waqf assets. Finterra's preferred block chain option is the Ethereum platform called Endowment Chain. Ethereum is one of the leading digital (cryptocurrency) currencies and has a Sharia-compliant nature. An Endowment Chain that allows participants to submit proposals to develop waqf assets and seek support from various parties to donate funds. If the proposal is accepted, the number of waqf tokens at a given rate will be generated and distributed to the contributors. These tokens can be the rights of stakeholders and revenue sharing or transfer or exchange within a large Finterra ecosystem. For example, the waqf administration wants to build a project on a waqf land for educational or housing purposes, all it needs is capital. In this case, it is difficult because financial institutions usually take a long time to provide loans, while government grants are too difficult or complicated. This is where the Endowment Chain will help. What needs to be done is through a process called the Land Organization Domain Model of the International Organization for Standardization (ISO). This process determines the level of trust of the project. If successful, at a later stage, the block chain used will issue tokens to donors to raise capital. Finterra does not hold any fund management licenses; instead it has cooperation with other financial and banking institutions. Once the required funds reach the target, the financial institution will manage in collaboration with the waqf administration or any other recognized 
local waqf. The tokens distributed and the proceeds of the project will be automatically regulated in a contract system that also includes account, guarantee and token holders.

\section{Suggestions and Recommendations}

The role of BWI in managing and developing the waqf funds and waqf assets prospects in Indonesia requires the following items:

- Development efforts against professional nazhirs, especially those individuals or legal entities who are authorized and responsible for cash nazhirs. This improvement in the quality of nazhir human resources can be a tentative law and its benefits can be enjoyed by the nazhir collectively. (Aziz, M., 2015).

- Involvement of strategic business entities that move in the financial (especially Shariahbased) areas such as banks, cooperatives, Baitul wal Tamwil (BMT) and others, in the process of promoting and disseminating cash waqf which is being developed by BWI. All of these help the prospect of waqf and increase public confidence in cash waqf in BWI.

- Nazhir plays an important role in the process of waqf development. Therefore, it is important to educate them so that they are knowledgeable and competent as nazhirs. BWI can carry out continuous education, development and training programs for nazhirs in helping them realize the management and development of waqf assets together (Dahlan, R., 2015).

- BWI can work with various government agencies to obtain waqf-related data such as the Ministry of Home Affairs and request cooperation for each Province and Regency / City in Indonesia to conduct surveys on their respective waqfs. The BWI may also provide the required questionnaire forms and be monitored by the respective Mayor.

- The BWI should also report on the activities and financial status of the institution. The absence of the Annual Report by the relevant authorities and the relevant information has led to the public's confidence in waqf institutions eroding (Ihsan M. H, 2007; Ihsan, H., \& Ibrahim, S. H. H. M., 2011). In addition, the BWI also needs to establish support rules regarding penalties in cases of noncompliance with officers and this should be enforced (Huda, M., 2012).

- The task coordination should be made between KEMENAG, BWI and the nazhirs registered under BWI so that no waqf related tasks overlap.

- Continuous education to the Muslim community in Indonesia on waqf needs to be done to provide a clear understanding of the concepts, advantages and practices of contemporary waqf. In addition, it can help waqf givers to perform cash waqf or waqf assets to suit the needs of the Muslim community in Indonesia.

- Use of technologies such as block chain in waqf. Finteraa Company has introduced an Endowment Chain that allows participants to submit proposals to develop waqf assets and seek support from various parties to donate funds. BWI should learn this block chain technology as it can speed up waqf asset documentation in Indonesia. At the same time, the use of block chain or crypto philanthropy for crowdfunding can address the issue of lack of funds for waqf development in Indonesia.

\section{Conclusion}

In summary, it can be concluded that the role of BWI in managing, developing and preserving waqf funds in Indonesia is very important. In the administration, it is noted that there are still some gaps in the Indonesian Waqf Board. In dealing with these issues, the support of the government and the cooperation of all parties is very important so that all future issues can be addressed easily and effectively. 


\section{References}

Aden, R., Effendi, D. \& Busro. (2018). The Development of Waqf Management through Waqf Act in Indonesia (Note on Republic of Indonesia Act Number 41 of 2004 regarding Waqf). MADANIA Vol. 22, No. 1, June 2018. DOI: 10.29300/madania.v22i1.881.

Aslam, M. M. H., Kamil, M. N. K., \& Ayuniyyah, Q. (2017). Development of Waqf in Indonesia: The Swot Analysis of Indonesia Waqf Board (BWI). AL-INFAQ: Jurnal Ekonomi Islam. Vol. 8 No. 2, December. DOI: 10.32507/ajei.v8i2.16.

Aziz, M. (2015). Peran Badan Wakaf Indonesia (BWI) dalam Mengembangkan Prospek Wakaf Uang di Indonesia. AL-AWQAF: Jurnal Wakaf dan Ekonomi Islam. Volume 8 No. 2 Edisi Julai, p: 145-162.

Badan Wakaf Indonesia. (2016). Fenomena Wakaf di Indonesia: Tantangan menuju Wakaf Produktif. Jakarta: Indonesia.

Badan Wakaf Indonesia. (2019). https://www.bwi.go.id/profil-badan-wakaf-indonesia/. Retrieved on $11^{\text {th }}$ November 2019.

Bank Wakaf Ventura. (2017). https://www.indonesiana.id/read/115568/merindukan-bankwakaf- ventura. Retrieved on $13^{\text {th }}$ November 2019.

Dahlan, R. (2015). Persepsi Nazhir Terhadap Wakaf Uang. AL-AWQAF: Jurnal Wakaf dan Ekonomi Islam. Volume 8 No. 2 Edisi July 2015. p: 128-144.

Department Agama Republik Indonesia. (2004). Panduan Pemberdayaan Tanah Wakaf Produktif di Indonesia.Direktorat Bimas Islam dan Penyelenggaraan Haji. Jakarta: Indonesia.

Dompet Dhuafa. (2019). Tabung Wakaf Indonesia. http://tabungwakaf.com/. Retrieved on $13^{\text {th }}$ November 2019.

Global Religion. (2019). Jumlah Penduduk Islam di Indonesia. https://databoks.katadata.co.id/datapublish/2019/09/24/berapa-jumlah-pendudukmuslim-indonesia. Retrieved on $14^{\text {th }}$ November 2019.

Havita, G., Sayekti, K. A., \& Wafiroh, S. R. (2014). Model Bank Wakaf di Indonesia Dalam Potensinya Untuk Mengembangkan Wakaf Uang dan Mengatasi Kemiskinan.In Program Kreativitas Mahasiswa-Gagasan Tertulis.

Huda, M. (2012). Arah Pembaruan Hukum Wakaf Indonesia. ULUMUNA. Retrieved from http://ejurnal.iainmataram.ac.id/index.php/ulumuna/article/view/192/186.

Hukum Online. (2017). Dilema Perbankan Syariah. https://www.hukumonline.com/berita/baca/lt58abf0a7010df/dilema-perbankan syariah-kelola-dana-wakaf. Retrieved on $15^{\text {th }}$ November 2019.

Ihsan M. H (2007). Towards the Improvement of Waqf Accountability in Indonesia: A Critical Review of the Act No 41 / 2004 on Waqf. Jurnal Akuntansi \& Manajemen, 2(2) p: 71-80.

Ihsan, H., \& Ibrahim, S. H. H. M. (2011). WAQF accounting and management in Indonesian WAQF institutions: The cases of two WAQF foundations. Humanomics, 27(4), 252269. http://doi.org/10.1108/08288661111181305.

Ikhsanudin, M. (2012). Optimalisasi Wakaf Produktif Bagi Lembaga Pendidikan dan Ormas Islam di Indonesia. Mukaddimah, 18(1).

Long, A.S. (2011). Pengenalan Metodologi Penyelidikan Islam. Penerbit UKM: Bangi, Selangor.

Nani Almuin. (2019). Interview, Manager, Divisi Penelitian dan Pengembangan Badan Wakaf Indonesia, Gedung Bayt Al-Quran Lt. 2, Jalan Pintu Utama TMII, Jakarta Timur 13560 ,

February 6, 2019, at 11.00 am. 
Kapital. (2019). Finterra Perkenalkan Blockchain Yang Akan Selesaikan Masalah Wakaf. https://kapital.my/2018/06/finterra-perkenalkan-blockchain-yang-akan-selesaikanmasalah-wakaf/. Retrieved on $13^{\text {th }}$ November 2019.

Kementerian Agama Republik Indonesia (KEMENAG). (2019). https://bimasislam.kemenag.go.id/. Retrieved on $15^{\text {th }}$ November 2019.

Waqf Act No 41/2004.

Zaenal, M. H. (2017). Aplikasi Wakaf Kontemporari dalam Konteks Filantropi Islam: Kajian Persepsi Masyarakat di Indonesia dan Malaysia. Doctoral theses. National University of Malaysia: Bangi, Selangor. 